\title{
Towards an African theological ethic of earth care: Encountering the Tonga Iwiindi of Simaamba of Zambia in the face of the ecological crisis
}

Author:
Kapya Kaoma'
Affiliation:
${ }^{1}$ Center for Global Christianity
and Mission, Boston
University School of
Theology, United States
Corresponding author:
Kapya Kaoma,
jkaoma@bu.edu
Dates:
Received: 10 Aug. 2016
Accepted: 12 Aug. 2017
Published: 30 Nov. 2017
How to cite this article:
Kaoma, K., 2017, 'Towards an
African theological ethic of
earth care: Encountering the
Tonga Iwiindi of Simaamba of
Zambia in the face of the
ecological crisis', HTS
Teologiese Studies/
Thead
Theological Studies $73(3)$,
a3834. https://doi.org/
10.4102/hts.v73i3.3834
Copyright:
Co 2017. The Authors.
Licensee: AOSIS. This work
is licensed under the
Creative Commons
Attribution License.

The mounting ecological catastrophe and its negative effects on humanity and future generations of life, demand proactive actions. The ongoing crises of deforestation, air and water pollution, land degradation and many other ecological predicaments are critical global moral and justice issues. Although postcolonial Africa's economic theories undermine the integrity of Creation, Africans are equally responsible. Following Pope Francis' invitation to Creation care, I argue that the lwiindi [the annual rain-calling ceremony] illustrates ecological concerns and possesses ecological insights that can aid, inform and positively transform Africa's ecological actions. The article opens with a brief discussion on the growing ecological consciousness in global Christianity and Africa. It employs the lwiindi to illustrate the ecological role of ancestors as guardians of the land. It is from this perspective that the Enlightenment influenced concept of 'progress', is examined. The article concludes with some critical reflections on the environment and Tonga culture.

\section{Introduction}

In June 2015, Pope Francis released his Encyclical Laudato Si' in which he followed St. Francis of Assisi's presentation of Earth as 'a sister with whom we share our life and a beautiful mother who opens her arms to embrace us' (Francis 2015a:par. 1). In addition to pronouncing the sacred value of Creation, the Encyclical brought the plight of planet Earth and the poor to the centre of local and global politics. Despite the overwhelming signs and catastrophic effects of climate change and environmental degradation, the Pontiff positively invited humanity 'to work together' to care for planet Earth as 'our common home'. In his words:

The urgent challenge to protect our common home includes a concern to bring the whole human family together to seek a sustainable and integral development, for we know that things can change. Humanity still has the ability to work together in building our common home. (Francis 2015a:par. 13)

To address the growing economic gap between the rich and the poor, the Pontiff followed Brazilian theologian Leonardo Boff's conviction that ecological reflections 'must integrate questions of justice in debates on the environment, so as to hear both the cry of the earth and the cry of the poor' (Francis 2015a:par. 49). Accordingly, a better future is inconceivable without 'an integrated approach to combating poverty, restoring dignity to the excluded, and at the same time protecting nature' (Francis 2015a:par. 139). It is from this perspective that he invites 'ecological citizenship' (Francis 2015a:par. 13, 211), by which all humanity learns to positively relate to the natural world.

The Encyclical followed various Christian campaigns to arrest the mounting environmental crisis from the Anglican Communion, the World Council of Churches, the Lausanne Movement, the Orthodox Church and African Initiated Churches (Kaoma 2015:15). These religious voices have constantly been active at various UN Conferences of the Parties on Climate Change and were present at the 2012 Rio+20 UN Conference on Sustainable Development in Rio de Janeiro, Brazil. All these activities accorded humanity a chance to re-examine its attitudes towards Earth and the poor - catalysing the growing ecological consciousness across the globe.

In Africa, this consciousness is not new. From the 1995 execution of Nigerian Ogoni environmental activist, Ken Saro-Wiwa, to the Green Belt Movement of the late Wangari Maathai in Kenya and to African Earthkeepers of Marthinus Daneel in Zimbabwe (Daneel 2001), environmental consciousness is slowly becoming an African economic and political issue. This consciousness is also prompted by the increasing extreme weather events - heat waves, floods and landslides. These events are worsened by human activities - soil erosion, burning of fossil fuels, pollution, the felling of trees and the over-exploitation of the land. 
Zimbabwean and southern African respected artist, Oliver Mutukuzi represents this consciousness in Pindirai [intervene]. Mutukudzi asserts:
Vakuruwe pindirai
Elders intervene
Madzimambowe pindirai
Royal elders intervene
Madzimambowe pindirai
Royal elders intervene
Mhuri yenyu yapererwa neruzivo
Your family has run out of wisdom
Vana venyu kupererwa nenjere.
Your children have run out of ideas.

This song does not blame outsiders for the mounting ecological degradation but Africans. Although international exploitation plays a role in Africa's environmental degradation, the singer views the growing ecological crises as because of Africa's failure to safeguard the environment.

The contrast between traditional customs that protected and regulated human-nature relationship and our earth-killing lifestyles are present in this song. For example, felling of trees along the rivers and in sacred groves, was taboo. Today, people senselessly destroy forests (vanotema miti vasina ruzivo). Using Shona sayings, he bemoans such acts as skinning a skunk in the air we breathe (vanovhiya chidembo vari kumhepo), and poisoning the very wells from which we drink (kusvipira mutsime). Aside from speaking to the dire consequences of destroying the natural world, these sayings sagaciously point to the interconnectedness of the environmental and human well-being (Epstein \& Ferber 2011).

But Mutukudzi equally speaks to existential consequences of destroying the natural world:

$\begin{array}{ll}\text { Hatichina mumviri } & \text { We have no shade from the } \\ \text { trees } & \text { We have no poles for } \\ \text { Hatichina mapango } & \text { building } \\ \text { Wuwinho hatichina } & \text { We have no fish } \\ \text { Hove hatichina } & \text { What used to be a big dam } \\ \text { Raiva dziva rava zambuko } & \text { is now a road } \\ & \text { What used to be pools are } \\ \text { Aive madziva ave mazambuko. } & \text { now roads. }\end{array}$

Mutukudzi addresses diverse African communities - both in rural and urban areas. The need for shade, poles for construction of homes, fish and shrinking water bodies affect rural societies just as urban communities. Nonetheless, he specifically singles out pollution and irresponsible waste management in urban Africa. Today, he bemoans, rivers (kutsviirira munzizi segomba ramarara), towns and cities (votora marara vounganidza muberere) are filled with solid waste. Regrettably:

Tatadza kuchengeta masango

Kutadza kuchengeta nzizi
We have failed to care for the forests

We have failed to care for the rivers

$\begin{array}{ll}\text { Mhepo yekufema yangova utsi } & \text { Our air is smoke } \\ \text { Kusvipira mutsime } & \text { Spitting into the well } \\ \text { Vakuruwe pindirai! } & \text { Elders intervene! }\end{array}$

In these lines, Mutukudzi addresses negative human attitudes towards Creation, and their effects on our common life. Unless we wake up to this dire reality, the worsening environmental degradation is to our own demise. For this very reason, African elders (vakuru or madzimambo) ought to intervene to avert this catastrophe.

It is important to note that the African traditional ontology informs Mutukudzi's call for the intervention of the elders. In this ontology, however, 'elders' (vakuru or madzimambo) includes 'ancestors' (Fortes 1981:304-319; Kopytoff 1971:129142; Setiloane 1986:17).

Although the object of Mutukudzi's appeal is unclear, Kaoma (2013) maintains that:

This unclear differentiation between the authority of the 'living elders' and 'ancestors' has been at the center of theological and anthropological contention when attempting to understand the power of ancestors in Africa. Nonetheless, the ancestors' lasting relationship with the lands they founded made them standards of morality. They are therefore obliged to intervene in any crisis that threatens their lands. (p. 32)

This appeal is intentionally directed to both the living elders, and to ancestors. This is because the destruction of the Earth is happening under the watch of our living elders - religious, traditional and political leaders. Because elders are associated with wisdom, the ensuing ecological crisis reflects their failure to instil ecological consciousness in their people. As for the living-dead elders (ancestors), they are the primal guardians of the Earth. In this frame, their role in arresting the occurring crisis must be sought.

Nonetheless, the specific intervention points are implied rather than identified. Implied in this song is the obligation of Africans to return to ecological friendly values that protect and relate to the natural world as the abode of the sacred and ancestors. Such values define Africans - we are daughters and sons of the Soil: the people of Earth.

Besides, the ecological crisis threatens cultural identity. We humans are products of our environments. As Maathai (2009) writes:

all human beings, wherever we were born or grew up, the environment fostered our values, nurtured our bodies, and developed our religions. It defined who we are and how we see ourselves. (p. 177)

Among the Tonga of Simaamba, for instance, the lwiindi [raincalling ritual] is not only about cultural identity, but also illustrates the ecological concerns of ancestors or elders. But first, let us have some words on the Tonga community culture. ${ }^{1}$

1.I retain "tribe" when citing others, but use community culture instead of 'tribe' in all my work. Tribe suggests that such communities are inferior. 


\section{Simaamba Gwembe elders or ancestors as guardians of the land}

The people of Simaamba belong to the Valley Tonga community cultures of the lower Zambezi, relocated in 1958 to the Zambian side during the construction of the Kariba Dam. The land of Simaamba includes the Town of Siavonga, though the palace is located about 30 miles from the town. The chiefdom is made up of two senior sikatongos [ecological guardians]: sikatongo Nambwele (who according to Charles Halubanje, the reigning Nambwele, is traditionally the correct person to perform the lwiindi) and sikatongo Hakuyu. Simaamba borders with the Tonga of Chief Chipepo (resettled around the Lusitu area) and the Goba (Shona) community culture of chief Sikongo.

The people of Simaamba trace their ancestry through the female line. Inheritance to the throne of Simaamba, for example, is from the matrilineal line, and only the chief's nephews (not nieces) from his matrilineal line inherit the throne. As discussed below, royal women and deceased chiefs are buried in the malende [sacred groves], where the annual lwiindi ceremony is held.

\section{The people of Simaamba within the wider Tonga history}

The Gwembe Tonga history is highly complex. Whereas the word 'Gwembe' was a Ndebele/Nguni name for the Zambezi Valley, today it is employed for all the community cultures of the Zambezi Valley. Equally foreign is the word 'Tonga', which describes Gwembe people. According to Colson and Gluckman (1959:1), the origin of the word is unknown, thus of foreign origin. The closest one comes to understanding its meaning is from F.M.T. Posselt, who, according to Lancaster, concluded in 1927 that Tonga referred to 'those who do not recognize a paramount chief, or faultfinders or grumblers' (Lancaster 1974). In 1938, F.B. Macrae also wrote:

[The Tonga] appear to have come into the area about a hundred years ago, according to their own tradition. At this time they say that the Valley was uninhabited. They also say they came from a country called Bunyai further down the river; this name is still to be found on the maps as Banyai, a tribe who were at one time prominent on the lower reaches of the Zambezi. The Banyai were also associated with the Makalanga [sic], ${ }^{2}$ a number of whom live with the Batonga in the Gwembe Valley at the present day. (p. 446)

While these scholars did not consider the Shona word, ' $k$ utonga' [to rule or judge], it is probable that Tonga referred to groups who sought to rule (the verb kutonga) themselves. The Shona origin of this name can also be adduced from the names Banyai and Makaranga (Southern Shona), which once described Shona communities around the Zambezi. This assertion is complemented by Lancaster's (1974) oral evidence that suggests that: the Tonga never had any real chiefs or paramount [chiefs] except Mambo [a Rozvi King] south of the Zambezi whom they ran from to be free. So they were called Tongas, which means grunters, dissatisfied people who complained and rebelled against their chief. (p. 724)

Hence, the word Tonga seems to be a 'descriptive term that refers to a cultural status deriving from Southern Rhodesian (Zimbabwean) history as Shona speakers see it' (Lancaster 1974; Matthews 2007).

Unlike the term 'Gwembe', today 'Tonga' is applied to diverse ethnic groups in Malawi, Mozambique, South Africa, Zambia and Zimbabwe. In Zambia, for example, 'Tonga' describes both plateau and valley community cultures. Some of these groups, however, are historically and linguistically unrelated. Scudder, one of the leading scholars of the Tonga, writes, 'Chipepo's, Sinazongwe's and Mwemba's people speak dialects of chiTonga of Central Bantu linguistic origin, while the earlier languages of the Sikongo and Simamba's peoples were of Southern Bantu linguistic origin'. Scudder further notes that 'major differences in culture, belief systems, and social organization (matrilineal versus patrilineal as well as differences in the nature and importance of lwiindi) exist between these various Gwembe communities' (Colson 1962; Scudder 2013). Unlike other Tonga cultures who refer to royal ancestral spirits as basangu, the people of Simaamba interchangeably employ mhondolo and basungu to refer to such spirits (Hamunteka 2009). ${ }^{3}$ Yet, despite lacking a common history and linguistic differences, Tonga community cultures are incorrectly perceived as a single social and cultural unit. These observations are critical to the study of the lwiindi - the ceremony differs from one community culture to another.

\section{The ecological and sociological landscape of the Gwembe Valley}

The ecological landscape of the Gwembe Valley has always been challenging (Cliggett 2005; Colson 1960; 1971; Scudder 1973; 1962). Aside from geographical hardships, the Valley was inhabited by many animal species, making it unhealthy for human habitation. Although the area received or still receives less rainfall than the rest of the country (Macrae 1938:446), the lack of rainfall was compensated by two farming seasons - during the rainy season and after the floods. Whereas the fertile alluvial soil attracted many people to the Valley, land productivity highly depended on balanced rainfall - too much or too little led to starvation. During such times, however, edible flora and fauna from the Valley supplemented Tonga diet. These ecological challenges seem to explain the supremacy of the lwiindi among the Tonga of Simaamba (Kaoma 2013:35). But they also affected Tonga socio-political organisation.

It is critical to note that the Tonga people were amorphous societies - the point attested to by various scholars (Colson 2006; Matthews 2007). Unlike other communities, the Tonga

3.In Shona culture, mhondoro describes prophetic figures such as Nehanda, Kaguv and Chaminuka. Unless specified, I retain basangu in this article. 
had no established monarchies or chiefdoms. In this regard, the office of the chief is a colonial creation. Moreover, the colonial and neo-colonial translation of the word mwaami as 'chief' became the lenses though which Tonga pre-colonial social organisation was understood. Like in pre-colonial Ila cosmology (Smith \& Dale 1920:74), mwaami referred to mediums of spirits or prophets and occasionally to sikatongos. The absence of chiefs also speaks to the cultural identity of the Tonga as noted above.

Nonetheless, being amorphous communities, they were easy targets of slave-raiding cultures. To protect themselves, charismatic sikatongos employed their ecological authority to counter-organise against slave-raiding groups. As Matthews writes, 'there are signs that certain Tonga groups adapted to the exigencies of trade and defense in the nineteenth century, and in places earlier, by strengthening and secularizing leadership positions' (Matthews 2007:15).

Besides, the centrality of the sikatongo in wider Tonga life suggests that they lived in 'ecological states' as opposed to 'political' communities. As products of the Westphalia project, however, colonial authorities and missionaries translated the sikatongo's ecological leadership into the office of the 'chief' in their application of Frederick Lugard's theory of indirect rule. This is because the ecological office carried some 'political' overtones.

\section{The Simaamba Tonga cosmology}

Like the Chishinga people of Zambia (Kaoma 2015), the Tonga believe in the ontological hierarchy of vital forces. Leza [God] is the Supreme Vital force, and the source of all life. The baami bamfula [chiefs of rain], who include royal ancestors (basangu) and other nature spirits are second in this hierarchy. These spiritual forces are not abstract beings in this worldview; they are encountered in the malende [sacred groves]. The malende are generally characterised by some form of natural objects - rocks, forests, springs and even mountains. Aside from being sacred ritual spaces where 'neighborhood representatives make appeal in times of stress, especially in drought years' (Colson 2006:66-67), among the Tonga of Simaamba, royal graves are also the malende. But such malende are marked by several tiny huts (kaanda). As the sacred abodes of the ancestors, the misuse of the malende is believed to invite:

general disaster for the community, unless the offenders were punished and a ritual of cleansing performed. If it is discovered that someone has cut the wood in the immediate vicinity of a shrine, he is ordered to pay a black chicken. (Colson 1948:275)

The basangu are easily conflated with the Supreme Being. In his expedition of the Zambezi from 1895 to 1900, Gibbons mistook the malende of the serpentine spirit Nyami-Nyami at Kariba Gorge as the headquarters of the Tonga God. 'This', he noted:

the boys assured me to be the headquarters of the great river god; and although many boats have gone down within these sacred precincts, neither boat, nor goods nor bodies have ever been recovered. The Portuguese ... always throw in wine and calico to propitiate the deity. (Gibbons 1907:45-46)

Unlike Gibbons, however, in Kariba: The Struggle with the River God, Clements (1959) writes:

it is not clear what status Nyami-Nyami had as an ancestral shade, but it caused those foolish enough to shoot the Kariba Gorge to disappear from the face of the Earth, and its tail was blamed for the destruction of bridges and coffer dams. (p. 12)

The people of Simaamba, Sikongo and Chipepo did not only describe Nyami-Nyami as the very powerful spirit, but like Chief Simaamba, they argued that 'Nyami-Nyami is a creature of God (Leza) and one of the most powerful spirits of the Zambezi' (Simaamba 2006).

Just below the basangu are family ancestors (mizimu). Unlike the basang $u$ whose roles extend to the whole neighbourhood, mizimu are guardians of the family line. Both the basangu and mizimu can possess individuals (ngangas) with healing powers. Although such individuals occasionally call the lwiindi, ngangas' activities are tailored to individual and family needs.

The relationship between the basangu and mizimu is confusing. During the lwiindi of Simaamba, for instance, the basangu and mizimu are invoked interchangeably. Likewise, the individuals who are possessed by the muzimo [singular] or the musangu [singular] spirits can interchangeably claim to be prophets or mediums of these spirits. Because the basangu intermediaries are usually held in higher esteem than the mizimu mediums, many mediums associate their powers with the basangu.

During the construction of the Kariba Dam, the complex relationship between the basangu and mizimu surfaced. Despite the threats posed by the dam, most people resisted resettlement for various reasons. The Northern Rhodesia official report of the Commission on the violence that ensued during the building of the dam noted that the Tonga believed that Europeans would not close the dam (Northern Rhodesia 1958:9). It is telling that the report did not provide the basis for such beliefs, but the people point to traditional beliefs. The belief in the malende as sacred embodiments of the basang $u$ as well as the sanctions that accompanied their obliteration convinced people that the Dam would not stand. Aptly stated, the belief in Nyami-Nyami's powers to defend the Valley from western encroachment provided the Tonga rationale for this opposition (Clements 1959:88).

Scudder, however, argues that such a belief was only present among the Goba (Shona speaking) and Simaamba people. In an email, he writes:

Colson and I have found no evidence at all that the large majority, namely the Middle and Upper River Tonga, believed in Nyaminyami. Presumably one reason why the early authors dealing with Kariba mentioned Nyami-Nyami was because the river serpent was associated with the boiling waters of the Kariba Gorge which was centered in Simamba Chieftaincy. (Scudder 2013) 
Nonetheless, in contemporary Tonga culture, the belief in Nyami-Nyami has become the oppositional lens through which the Gwembe Tonga identity is now interpreted and contested. Others, however, feared the wrath of their mizimu [ancestors] if they abandoned their ancestral graves.

To calm these fears, prophets provided spiritual direction. Although they previously prophesised doom should people abandon their matongo [ancestral lands], after some negotiations with colonial officials, the basangu agreed to move following certain rituals. They instructed people to carry the soil, logs and branches from their sacred groves as a way of bringing their ancestors into the new environment. Mr Patrick Makukisi, a resident of chief Chipepo's area and a key informant to this research, was 11 years old at the time of the resettlement. When asked to explain how his family survived the Lusitu condition - the illness that led to the death of many relocated Tongas - he explained:

I remember what my father did. He followed the instructions of the basangu and carried the soil with him. When we got to Lusitu, he mixed it with water and gave us to drink. That is why we survived. (Makukisi 2006)

Nonetheless, such innovations did not convince all Tongas; some defended their land with their own lives - leading to violent clashes between colonial authorities and the Tonga. The violent clashes, the defeat, the forceful removal and finally the closing of the dam walls led some Tongas to question the powers of the basangu over Western forces. However, the deaths and the droughts that followed the resettlements reconfirmed their original reservations - their ancestors were offended.

The Kariba case illustrates the influence of the basangu not only over the lwiindi but also over new socio-economic and political changes in Tonga life. The solidification of the authority of sikatongos [chief] Monze and [chief] Mweemba in Tonga history was because of their ecological roles as basangu prophets. Just as Mbuya Nehanda and Sekuru Kaguvi of Mashonaland used their prophetic powers to resist colonial rule in today's Zimbabwe, Monze employed his ritual authority to resist Lewanika of the Lozi, and later colonialism in Northern Rhodesia or Zambia.

\section{Ritual actors in the /wiindi of the Bagande (frog) clan of Simaamba}

Various scholars have explored various lwiindi ceremonies of the Valley (Colson 2006; O'Brien \& O'Brien 1997), but the lwiindi of Simaamba is understudied. Whereas the lwiindi is the prerogative of the sikatongo [Earth priest], among the people of Simaamba, the chief officiates. But equally important is the woman known as mulela (from the verb kulela, 'to care'). Aside from being the official keeper of the ganda (sacred hut where the chief spends special nights, and traditional artefacts are kept), the mulela is also the keeper of the royal artefacts. Generally, she is selected among the virgins from the line of the mulela. She is a ritual wife and takes care of all the needs of the chief while in the ganda.
In addition to the mulela, there is the muzambi. Because of his knowledge of preventative traditional medicines, he is the spiritual bodyguard to the chief. ${ }^{4}$ During the ceremony, the muzambi consults with the chief and protects him against all evil powers. Traditionally, however, his other duties included sampling foods, especially in times of famine. A muzambi would sample wild roots first; if he dies, the chief would not consume it.

The two sikatongos Nambwele and Hakuyu are equally important to the ceremony. They present the needs of their respective neighbourhoods to the chief during the ceremony. This role follows the African tradition of employing elders to speak on behalf of the young. 'If I am young, I go to my elders who happen to be alive', Kopytoff writes:

The old people go to their elders; but since these are dead, they are to be found at the grave or at the cross-roads at night. - The elders are the representatives of the ancestors and the mediators between them and the kin-group. (Kopytoff 1971:133, 140; Setiloane 1986:17)

Finally, the first wives of the chief, the two sikatongos and the senior muzambi take part in the lwiindi. They provide ritual water to their husbands during the ceremony.

\section{Explaining the Iwiindi ceremony of Simaamba}

The lwiindi of Simaamba is held around October and November when people are preparing their fields. This is because they believe that without the blessings of their ancestors, the fertility of the land is compromised. In this ontology, the chief is obliged to supplicate the basangu for good rains and harvests.

The lwiindi cannot be performed without kankata - the traditional beers. Each household contributes the grain for brewing the beers. The grain (sorghum, millet and maize) is then given to 'old' women, who brew kankata.

A week before the ceremony, the chief and the mulela enter the sacred hut (ganda). Sample seeds are placed under their bed, and the couple is excluded from all social activities. This exclusion extends to the entire community. While the chief and the mulela are in the ganda, community elders prepare or rebuild the sacred huts (nsaka) at the malende. These huts are considered dwelling places of the basangu [royal ancestors]. Because ancestorhood is accorded to both men and women of the royal line:

the gender of a specific ancestor is symbolized by the way the hut is thatched. Males have their huts thatched with the roof having grass shaped like horns, while female huts are identified by a cone. (Kaoma 2013:42)

The evening before the ceremony kankata is offered to royal ancestors in the malende. Unlike other African cultures that pour the beers on the ground as libation to ancestors, 4.According to Sikatongo Nambwele (2006), traditionally a muzambi was picked among slaves. 
Simaamba Tongas put kankata in small clay pots, which are then placed in each hut. After invoking the ancestors to accept their people's offerings, the party departs until the following day.

On the morning of the lwiindi, people gather around the ganda to await the chief's coming-out ceremony. The two sikatongos Hakuyu and Nambwele, however, wait within the vicinity of the malende. They will join the procession at two different intervals during the ceremony. ${ }^{5}$ At the palace, other chiefs, invited guests including government officials and children are entertained by various rain-calling songs by drummers and dancers. Whereas this article is not about the dance, it is important to note that Simaamba drums are designed differently from those of Chipepo-again suggesting their Shona roots. In addition, the people and the chief generally dance in a circular fashion. In addition to forming the circle around the drummers, dancers move around in a circle, which seems to suggest the circular concept of time and life (Kaoma 2013:75-81).

As the crowd grows, the muzambi enters the ganda to alert the chief to come out. At this moment, the mulela hands the chief traditional spears and a bukanu [axe] from the founding ancestor. In addition, she hands extra spears to the muzambi. Immediately thereafter, the muzambi emerges holding spears, and the mudima or budima [special beat] is played on drums. Immediately, people stop singing and the chief emerges from the ganda, dressed in his royal black gown, a hat and holding the bukanu. At this time people make loud sounds and gesticulations. The chief then leads an adult-only procession to the malende. ${ }^{6}$

As the parade makes its way into the malende, men and women separate. Women continue towards the place called nakalindi or cihiba [pool] while men go hunting in the sacred grove. The chief and his muzambi, however, await the hunting party under the sacred tree. Just as the hunting party rejoins the chief, sikatongo Nambwele and his men emerge from their hiding place to confront Simaamba with spears in an enacted war. Dressed in a black robe and a hat, and carrying his own bukanu and spears, sikatongo Nambwele leads his people into this war. Simaamba's people fight back until Nambwele recognises his authority. After making peace, they proceed towards the nakalindi, where they are met by dancing women. ${ }^{7}$

As the chief's party approaches nakalindi, sikatongo Hakuyu and his people confront them with spears. While holding his bukanu and dressed in a black gown and a hat, and holding spears, Hakuyu leads his people in this war. Again,

5.The joining of the sikatongos at different times symbolises how the three groups became part of the Simaamba royal establishment.

6.This is in contrast to Colson's (1948:280) findings among the Plateau Tonga where no one is excluded from the Iwiindi. She nonetheless asserts that the Luanga Tonga exclude women from the ceremony.

7.In an interview, Mr Simaamba Jr (2006), the son of the late immediate chief .In an interview, Mr Simaamba Jr (2006), the son of the late immediate chief his sikatongos whenever he wants to find out how their respective katongos are doing. It is a place where each sikatongo makes a report and advice is given to, and by the chief'. after this enacted battle, Hakuyu accepts the authority of Simaamba and joins the party. The chiefdom of Simaamba is now complete.

Here it is important to note the amorphous or ecological nature of the people of Simaamba is again revealed in these wars. Unlike the people of Chipepo who carry spears and shields, the people of Simaamba do not carry war shields.

That said, the above encounters between the two sikatongos and the chief illustrate how many African communities dealt with differences. While conflicts existed, communities finally accepted each other. This is evident in the ceremony as people from the three sikatongos (Simaamba, Hakuyu and Nambwele) celebrate their unity with dancing for several minutes while the three traditional leaders are standing-by until the chief raises his bukanu. After everybody is quiet, a ritual of water-drinking is performed with the chief being served first by his first wife (the Tonga usually marry more than one wife). Likewise, his muzambi and sikatongos are served by their first wives. (While traditionally the water for this ritual came from the nakalindi, today tap water is used.) The drinking of the water collected from nakalindi is meant to celebrate the initial blessings of the ancestors with the rains. This ritual is followed by the roll call. Whenever each neighbourhood is called, the people from that area shout with joy. If the chief senses that very few people came from a specific neighbourhood, he entreats that particular sikatongo to encourage his people to come in numbers the following year.

The Chief then greets his sikatongos beginning with Nambwele:

Ndakwaanzya Hacihibi! [I greet you, Hacihibi].

Nambwele responds: kukaita ku kajiba [you greet me because you know me].

Thereafter, he greets Hakuyu:

Ndakwaanzya Hakuyu! [I greet you, Hakuyu].

Hakuyu responds: Tulinamuntengwe tutandila busi [We are like the Southern black flycatcher, we follow the smoke]. ${ }^{8}$

After these greetings, the chief asks his sikatongos about the ecological status of their neighbourhoods. Generally, the sikatongos alert the chief to hunger-related sufferings of their people. They then petition the chief to ask the basangu for good rains and harvests.

The sikatongos' requests are followed by dancing women who similarly solicit the chief for rain in an artistic fashion. Unlike the sikatongos who simply make verbal supplications while standing, women do it through dancing, clapping and kneeling before the chief. After receiving all the requests, the chief, on behalf of the living elders, leads the procession towards the royal graves. Sikatongo Nambwele, however, 8.The greeting illustrates Hakuyu's role in Simaamba's neighbourhood, always prepared to aid whenever needed. 
remains behind because he is prohibited from visiting Simaamba's royal graves. ${ }^{9}$

Simaamba royal graves resemble a Tonga village, but with very small round huts. Because each hut is home to each ancestor, the party checks individual huts to determine whether their gifts are accepted. Writing about the Tonga people of Nyasaland (Malawi) in 1907, MacAlpine (1907) explains:

If the frothy scum on the beer has been disturbed, or if any of the offering seemed to be less in quantity than when they had been placed in position, the omen was good. If no change was noticeable, they judged that they and their gifts had been unfavorably received, and they set themselves to gain favor by larger and better sacrifices. (p. 380)

MacAlpine's observation partially applies to the lwiindi of Simaamba. Nonetheless, Simaamba Tongas supplicate each ancestor separately. If the scum is disturbed in a particular hut, that specific ancestor is pleased with them. Should the scum in another hut remain undisturbed, that particular ancestor is unhappy. At the 2006 lwiindi, for example, the scum in the immediate late chief's malende (the reigning Simaamba's uncle) was undisturbed and people interpreted it as indicative of the unfavourable relationship between the reigning Simaamba and his predecessor.

Unlike MacAlpine's study, the chief did not make another big sacrifice, but employed verbal confessions and dialogical appeals to his late uncle. As if speaking to a living person, the chief reminded his uncle that he too made many mistakes and annoyed the ancestors during his reign. However, when he asked for forgiveness, they forgave him. He then continued, 'If we, your people, have done wrong, we ask for your forgiveness and implore you to accept our gifts'. Thereafter, he danced around the shrine for many minutes.

After visiting and dancing around all the graves, a general request for abundant rain and the help of ancestors in controlling rats, insects, birds and anything that can thwart good harvest is finally made to the basangu. These supplications seem to follow the Christian pattern - the chief as the priest on behalf of his people calls on the basangu to provide for their progenies. Furthermore, the appeal to the ancestors to control other creatures is an excellent example of how the Tonga perceive and relate to non-human beings they are under the control of their ancestors. Rather than killing them with pesticides, they ask ancestors to control them.

After this appeal, the chief leads his party back to nakalindi, where sikatongo Nambwele rejoins the procession back to the ganda. Because children, young people and nursing women are not generally allowed to visit the malende, they eagerly await the chief's return outside the vicinity of the grove.

\footnotetext{
9.According to Sikatongo Nambwele, it was a taboo for him and Simaamba to meet face-to-face except during the Iwiindi. 'In the past, if I saw him (Simaamba) coming, I would change direction. Today, however, we meet' (Hamunteka 2009). By responding, 'You greet me because you know me', Nambwele seems to be pointing to this belief.
}

When the party emerges from the malende, the children, young people and nursing mothers come running towards the procession. They then rejoin the procession as it makes its way to the ganda. Upon reaching the ganda, the chief performs his final dance around it for many minutes - circling the ganda in an artistic fashion. Thereafter, he retires into the ganda, where the mulela reclaims the spears and all artefacts. The chief is now free to go back to his palace, change clothes and entertain guests. The lwiindi celebrations continue with feasting, traditional dances and other social activities at Simaamba school grounds. ${ }^{10}$

\section{Ecological overtones of the Iwiindi}

The lwiindi ceremony speaks to the ecological role of ancestors in Tonga worldviews. Despite calling on the basangu for rains, the people of Simaamba understand Leza as the sole rain giver, under whose authority the basangu exist. Rain is only granted 'through their intervention with Leza, a god who controls all things' (Colson 2006:51, 277).

That said, the lwiindi is not an ancestral cult per se, but the ceremony has many aspects of the same. In God's Family, God's Earth, Kaoma (2013) who views the ancestor cult as an earthly cult writes:

To treat the cult of ancestors as merely addressing social, religious, and political issues is to ignore the ecological significance of the cult in African religions. In fact, one can go further and say that the ancestor cult is the cult of Earth because it seeks to uphold the ecological balance of the ecosphere. (p. 53)

In addition, the sikatongo is obliged to protect the land against forces that compromise ecological harmony. Unexplained illnesses, for instance, are explained ecologically - thus the sikatongo's role is holistic. In this regard, performing the lwiindi is just one of the many duties of the sikatongo. In line with Ladd and Soskolne's linkage of the negative effects of climate change on human health (Ladd \& Soskolne 2008), the Tonga understand human health ecologically.

The geographical appeal of the lwiindi of Simaamba is limited to the two sikatongos. Chief Monze's lwiindi, however, reaches across many Tonga communities. The positive reputation of sikatongo Monze as a successful rain caller in precolonial Tonga history, led the O'Briens to conclude that precolonial Tonga life was politically organised around him (O'Brien \& O'Brien 1997:519-541; O’Brien \& O'Brien 2007). This argument, however, is ahistorical - it contradicts Tonga social organisation discussed above. The power of the sikatongo, that is the ability to uphold the ecological balance of his land - both human and nonhuman beings, was not political, though it possessed political overtones. As Colson (2006) states:

The sikatongo is not per se a leader or ruler of men. He is of importance only in relation to his katongo which is specific to a neighborhood. Through him [people] relate themselves to the land on which they live, which provides their sustenance. In any 10.For studies on other Gwembe Iwiindis see Colson (1948), O'Brien (1983) and O’Brien and O'Brien (1997). 
other neighborhood, he is powerless. He cannot take his ritual position with him. (p. 65)

Colson's observation needs emphasising. The precolonial influence of Monze was confined to his neighbourhood (katongo). Because he was a successful rain caller and healer, Monze confronted ecological disasters and unexplained illnesses in his community - for this reason, he had a large neighbourhood. Charles Halubanje's (Nambwele) insistence that he is the rightful sikatongo to perform the lwiindi points to this historical tension. The possession of bukanu [the symbol of traditional authority] by the two sikatongos and the staged battles during the lwiindi suggest historical equality on the one hand, and the colonial subordination of the two sikatongos to Simaamba on the other hand.

Furthermore, the forced resettlement negatively impacted the lwiindi among the people of Simaamba. The loss of ancestral lands, coupled with the completion of the dam and forced resettlement, apparently indicated the failure of the basangu and mizimu to protect their people. Moreover, between 1960 and 1963, the relocatees had much better harvests than they got in the Valley. That the land could still produce without the help of Earth priests and basangu created a cognitive dissonance among relocatees. However, once the ecological conditions changed, the belief in the basang $u$ was revitalised - leading to the reinstatement of the lwiindi in Simaamba.

\section{Revisiting African ecological consciousness}

The sacredness associated with the sacred groves has potential to positively enhance Earth care. Nonetheless, amidst socioeconomic transformation of Africa, the respect accorded to sacred groves does not ensure perpetual protection from human exploitation. In his study of Shona sacred groves (marambatemwa), for example, Daneel (2001:9) shows how commercial and political interests threaten sacred groves.

Sheridan and Nyamweru (2008) maintain that sacred groves are social constructs:

[The] sacredness of groves is not the result of cultural values abstracted from their contexts in human lives. It is not in trees, plants, vines, springs, pools, rivers, and rocks. Sacredness is embedded in the social institutions that sacred groves manifest in African landscapes, which means that the ecological status of these patches follows from the shifting social organization of African societies and the flux of historical change on the continent. (p. 20)

While the respect accorded to sacred groves changes over time, with purposely renewed ecological spirituality of Creation, new sacred groves can be recreated. In his forthcoming book, Daneel shows how a Shona female prophet, Mbuya Juliana is recreating new sacred groves across Zimbabwe. This observation also speaks to the recreation of Simaamba malende - it is a post-resettlement phenomenon.

\section{Progress amidst environmental degradation}

The drinking of water from the tap as opposed to nakalindi and the dam testify to the socio-cultural transformation of the people of Simaamba. Whereas the lwiindi of Simaamba can be interpreted as a protest ritual against modernisation, the community exists between traditional cosmologies and civilisation. But with civilisation comes environmental degradation. Hardin writes, the 'history of human exploitation of the earth has produced this progression: colonize - destroy - move on' (Hardin 1993:17). Aside from viewing colonisation as 'a prelude to destruction and abandonment', Hardin writes, "The restless "moving on" of the human species has depended on always having fresh land to move to'. Unfortunately for communities like Simaamba, there is no fresh land to migrate to - their land is fixed while the population continues to grow.

Consequently, the building of the Kariba Dam was informed by the Enlightenment worldview. Because the idea was covered in the concept of 'progress', the project was another example of human capacity to colonise the natural world hence no effort was made to rescue animals (Lagus 1960). But as Hardin argues, until 1600 'the dominant worldview was a limited view: resources were limited, human nature was fixed, and spending beyond one's income was a sin' (Hardin 1993:3). Unfortunately, this worldview was replaced with the concept of limitless resources - making progress the ruling paradigm of Western society [one can add the globe]. It has penetrated every corner of our life; it is intimately connected with theories of population dynamics' (Böserup 1965; Brown 1989; Hardin 1993:23; Kalipeni 1994).

Whereas Hardin attaches progress to population dynamics, Pope Francis critiqued 'the myth of unlimited material progress' in relations to limited natural goods. 'A fragile world, entrusted by God to human care, challenges us to devise intelligent ways of directing, developing and limiting our power' (Francis 2015a:par. 78). Because of his opposition to gender theory (ideology of Gender), Pope Francis opposes all forms of contraceptives including abortion. He writes, 'Since everything is interrelated, [complementary], concern for the protection of nature is also incompatible with the justification of abortion' (Francis 2015a:par. 120; see also Francis 2015b). Yet, despite this difference, both advocate the new worldview that accepts the limitedness of natural goods. ${ }^{11}$

The displacement of the Tonga was equally controlled by the myth of progress or civilisation. The Tonga, however, did not value the Zambezi Valley through Enlightenment lenses they lived within the limits of the ecological challenges of the Valley. Such simple lifestyles were termed 'barbaric', while the limitless destruction of the natural world for imperial profits was called progress, civilisation and economic development - the trend that has continued to this day. Yet the theories - spaceship economics and cowboy economics. The first seeks to work within the confines of limited goods in the limited spaceship called planet Earth, while the later views such goods as limitless and can be exploited endlessly Cowboy economics works on the premise of exploiting the natural world without consideration of the poor - this position is highly promoted by US Conservatives. 
African morality of using Earth's natural goods is conditioned on the ethical negotiation of the needs of the living dead, the living and the living unborn. In other words, land belongs 'to the family of which many are dead, few are living, and countless members are unborn' (Elias 1956:162; Nkrumah 1959:10). ${ }^{12}$ Although the source of this saying is contested, the truth is, this belief no longer holds true - African land is in the hands of the 'select' and 'corrupt' few - masses are landless.

Upholding the balance between progress and environmental sustainability is critical to our common life, and to that of future generations of life. The conquering of the Earth's natural goods through industrialisation and civilisation (though celebrated as progress) threatens our interconnected ecological community. As Pope Francis observes, as a human family, we 'can cooperate as instruments of God for the care of creation, each according to his or her own culture, experience, involvements and talents' (Francis 2015a:14). For Africans, this entails returning to traditional ecological values that safeguarded sacred Earth. If we don't, we, Africans, are spitting into the well from which we drink.

\section{Concluding remarks}

The resurgence of traditional ecological ceremonies in contemporary Africa holds potential for illustrating ecological concerns. For instance, the lwiindi can be instrumental in transmitting ecological messages and values to ordinary people within their lifeworld. Scholars, policymakers, traditional, political and religious leaders as contemporary elders should explore such traditional ceremonies in attempts to arrest the mounting ecological crisis. In African Earthkeepers, Daneel shows how the high God cult of Mwari energised treeplanting and wildlife protection initiatives in Zimbabwe. By allowing Mwari's involvement in Earth care initiatives, both Christians and traditionalists became active participants in the missio Creatoris Dei [the mission of the Creator God]. Similarly, the lwiindi can aid reforestation programmes and land reclamation initiatives.

Furthermore, for Africans, the occurring ecological crisis is an identity crisis. The Pontiff speaks to this problem:

\begin{abstract}
Many intensive forms of environmental exploitation and degradation not only exhaust the resources which provide local communities with their livelihood, but also undo the social structures which, for a long time, shaped cultural identity and their sense of the meaning of life and community. The disappearance of a culture can be just as serious, or even more serious, than the disappearance of a species of plant or animal. (Francis 2015a:par. 145)
\end{abstract}

Abrahams (2016) makes a similar point when she writes and I cite at length:

12.The origin of this saying is disputed. Elias attributes it to the Nigerian chief's statement to the West African Lands Committee in 1912. Yemi Oke (2008:227-239), however, dates it to 1908 and identifies the chief as Elesi of Odogbulu in Nigeria. Regardless, the saying is part of the many African sayings about the value of land. It shares much with the Native American saying, 'We do about the value of land. It shares much with the Native American saying, '
not inherit the Earth from our Ancestors, we borrow it from our Children'.
Colonialism caused us to forget our core values, namely respect for immanent nature and one another. This caused an eschatological crisis from which we have not yet recovered.... We believed that God/de [sic] lived in mountains, trees and rivers, we practiced a respect for nature which ensured that we always lived within our means. We did not use more than what we needed, and because of this we always had enough. We did not cut more trees than would regrow, nor did we emit more carbon than our forests could absorb. In this way those simple religious beliefs protected both us, and our children for generations. Whether this was deliberately set about by our ancestors or whether environmental sustainability was simply a byproduct of an $u b u n t u$ which included all species and the entire ecosystem, is perhaps not the point. The point is that when we lost our sense of identity and traditional values we doomed our children and ourselves to everlasting poverty. (pp. 70-87)

Moreover, the gender-balancing role of the lwiindi and the belief in royal ancestors of both genders suggest egalitarian relationships in precolonial Tonga. The chief despite being the representative of the community cannot supplicate the ancestors without the mulela. Similarly, ancestors cannot provide abundant life to their descendants without the union between the mulela and the sikatongo - again suggesting gender harmony. This is not to say the lwiindi is gender affirming - other areas may need reforming.

Finally, the assumed inferiority of women is also evident during the supplication of the chief. While the sikatongos present their requests while standing, women do so by dancing, clapping and knelling before the chief. Similarly, the reservation of the throne solely to the nephews of the Chief assumes the superiority of men over women. In short, Tonga cultures may be matrilineal and possess positive ecological insights, but patriarchy needs confronting.

\section{Acknowledgements Competing interests}

The author declares that he has no financial or personal relationships which may have inappropriately influenced him in writing this article.

\section{References}

Abrahams, Y., 2016, 'Thank you for making me strong: Sexuality, gender and environmental spirituality', Journal of Theology in Southern Africa, Special Issue, Sexuality in Africa 155, 70-87.

Böserup, E., 1965, The conditions of agricultural growth: The economics of Agrarian change under population pressure, Aldine, Chicago, IL.

Brown, L.R., 1989, 'Feeding six billion', in World Watch Magazine, (September/ October), pp. 32-40.

Clements, F., 1959, Kariba: The struggle with the River God, Methuen, London.

Cliggett, L., 2005, Grains from grass: Aging, gender, and famine in rural Africa, Cornell University Press, New York.

Colson, E., 1948, 'Rain shrines of the Plateau Tonga of Northern Rhodesia', Africa: Journal of the International African Institute 18(4), 272-283. https://doi.org/ $10.2307 / 3180449$

Colson, E., 1960, Social organization of the Gwembe Tonga, Manchester University Press, Manchester.

Colson, E., 1962, The Plateau Tonga of Northern Rhodesia: Social and religious studies, Manchester University Press, Manchester.

Colson, E., 1971, The social consequences of resettlement, University of Zambia, Lusaka. 
Colson, E., 2006, Tonga religious life in the twentieth century, Bookworld Publishers, Lusaka.

Colson, E. \& Gluckman, M. (eds.), 1959, Seven tribes of Central Africa, Manchester University Press, Manchester, England.

Daneel, M., 2001, African earthkeepers: Wholistic interfaith mission, Orbis Books, Maryknoll, NY

Elias, O.T., 1956, The nature of African Customary Law, Manchester University Press, Manchester.

Epstein, P.R. \& Ferber, D., 2011, Changing planet, changing health: How the climate crisis threatens our health and what we can do about it, 1st edn., University of California Press, Berkeley, CA.

Fortes, M., 1981, 'The authority of ancestors', Man 16(2), 304-319.

Francis, P., 2015a, Laudato Si': On care for our common home, Melville House, Brooklyn, NY.

Francis, P., 2015b, Amoris Laetitia: The joy of love: On love in the family, Our Sunday Visitor Inc, Huntington, IN.

Gibbons, A.S.H., 1907, Africa from south to north through Marotseland 1, J. Lane, London.

Hardin, G., 1993, Living within limits: Ecology, economics, and population taboos, Oxford University Press, New York.

Kalipeni, E., 1994, Population growth and environmental degradation in Southern Africa, Lynne Rienner Pub., Boulder, CO.

Kaoma, K.J., 2013, God's family, God's earth: Christian ecological ethics of Ubuntu, Kachere Press, Zomba.

Kaoma, K.J., 2015, The creator's symphony: African Christianity, the plight of earth and the poor, Cluster Publications, Dorpspruit, Pietermaritzburg.

Kopytoff, I., 1971, 'Ancestors as elders in Africa', Africa: Journal of the International African Institute 41(2), 129-142. https://doi.org/10.2307/1159423

Ladd, B.D. \& Soskolne, C.L., 2008, 'A toolkit for ecoepidemiological enquiry under global 369 ecological change', in C.L. Soskolne \& L. Westra (eds.), Sustaining life on earth: Environmental and human health through global governance, pp. 369-382, Lexington Books, Lanham.

Lancaster, C.S., 1974, 'Ethnic identity, history, and "Tribe" in the Zambezi Valley', AmericanEthnologist1(4),707-730. https://doi.org/10.1525/ae.1974.1.4.02a00070

Lagus, C., 1960, Operation Noah, Coward-McCann, New York.

Maathai, W., 2009, The challenge for Africa, Pantheon Books, New York.
MacAlpine, A.G., 1907, 'Tonga religious belief and customs: 4. worship', Journal of the Royal African Society 6(24), 375-384.

Macrae, F.B., 1938, 'Some notes on part of the Gwembe Valley in Northern Rhodesia', The Geographical Journal 91(5), 446-449. https://doi.org/10.2307/1787506

Matthews, T., 2007, 'Notes on the precolonial history of the Tonga, with emphasis on the Upper River Gwembe and Victoria Falls area', in C. Lancaster \& K.P. Vickery (eds.), The Tonga-speaking peoples of Zambia and Zimbabwe, pp.13-33, University Press of America, New York.

Nkrumah, K., 1959, Ghana, T Nelson and Sons Ltd, Edinburgh.

Northern Rhodesia, 1958, Report of the commission appointed to inquire into the circumstances leading up to and surrounding the recent deaths and injuries caused by the use of firearms in the Gwembe District and matters relating thereto Government Printers, Lusaka.

O'Brien, D., 1983, 'Chief of rain - Chief of ruling: A reinterpretation of pre-colonial Tonga (Zambia) social and political structure', Journal of the International African Institute 53(4), 23-42. https://doi.org/10.2307/1159709

O'Brien, D. \& O'Brien, C., 1997, 'The Monze rain festival: The history of change in a religious cult in Zambia', The International Journal of African Historical Studies 29(3), 519-541. https://doi.org/10.2307/221359

O'Brien, D. \& O'Brien, C., 2007, 'Religious and group identity of the Tonga: An examination of the Lwiindi festival', in C. Lancaster \& K.P. Vickery (eds.), The Tonga-speaking peoples of Zambia and Zimbabwe: Essays in honour of Elizabeth Colson, pp. 63-81, University Press of America, Lanham, MD.

Oke, Y., 2008, 'Intergenerational sustainability and traditional knowledge in Africa: The natural resource management perspective', in C.L. Soskolne \& L. Westra (eds.), Sustaining life on earth: Environmental and human health through global governance, pp. 227-239, Lexington Books, Lanham.

Scudder, T., 1962, The Ecology of the Gwembe Tonga, Manchester University Press, Manchester.

Scudder, T., 1973, 'The human ecology of big projects: River Basin development and resettlement', Annual Review of Anthropology 2, 45-55.

Scudder, T., 2013, 'Email correspondence on my research on the Tonga of Simaamba', Wednesday, January 9

Setiloane, G.M., 1986, African theology: An introduction, p. 17, Skotaville Publishers, Johannesburg.

Sheridan, M.J. \& Nyamweru, C., 2008, African sacred groves: Ecological dynamics and social change, James Curry, Oxford.

Smith, E.W. \& Dale, A.M., 1920, The lla-speaking peoples of Northern Rhodesia, vol. 2 Macmillan and $\mathrm{Co}$, London. 